\title{
Have you all got your copy of the Qur'an? \\ Rationalisation, ritual and the role of God's word in a Kenyan Islamic educational setting
}

\author{
Af Jonas Svensson
}

This article concerns the discussions on and use of the Qur'an in the setting of Islamic Religious Education in Kisumu, Kenya. It is based on fieldwork conducted 2003 - 2006. Theoretically it uses a distinction between ritual and cognitive aspects of how the text is addressed. The author finds that the teaching is focused on the latter aspect. Hence, hypothetically the author argues, Islamic Religious Education, through the content and the form of the teaching as well as the position of the subject itself in the overall educational system, promotes a "demystification" of the text, providing it with a character that is quite different from the one dominating in the local Muslim context.

\section{Introduction}

Have you all got your copy of the Qur'an?

(Silence)

I told each one of you to get a copy of the Holy Qur'an.

One boy shows his copy of the Arabic Qur'an

No, no, no! An English translation! You should get an English translation. You have to be able to read and understand. This is important. How do you expect to pass the exams without an English translation of the Qur'an?

The Qur'an has its unquestioned place in the academic study of Islam, and it is approached in different ways. The Qur'an may be studied as a historical text, tied to the specific socio-historical context in which it was first produced. Questions can be asked pertaining to its original meaning, its relationship to other texts and to oral traditions. The text can also be viewed as bearing witness of specific historical events, mainly connected to the life of the Prophet Muhammad, and as such becomes a source for historiography. A historian of religion may be interested in the relationship between the ideas expressed in the Qur'an and earlier religious traditions. Moving away from the original context, the Qur'an itself has a history. How the text developed over time may also be a field of study. However controversial this historically oriented study of the text itself is today, it 
still has a given place in the academic study of Islam ${ }^{1}$

But the Qur'an is also a 'living text' in the sense that it has been, and is, a central part in the religious lives of Muslims throughout the world. It is perceived as the Word of God, and as such as an eternal guide for mankind, but also a vessel of extraordinary power. The Muslim religious study of the Qur'an may have a historical touch to it, but its main purpose is the exploration of its perceived eternal message, and the production of norms. The question on 'what the Qur'an says' is not, as in the secular academic study, a question of what meaning the text had in its original context, but rather on its perceived eternal message, relevant for all ages.

The Muslim religious approach to the text, in its diverse form, can also be a field for academic study. Here the focus is not so much on the text itself, but rather on how it is handled and understood by Muslims, as human beings situated in diverse social and cultural settings, contemporary or historical. The actual content of the Qur'an is here less important, compared to the issue of how Muslims (and at times also non-Muslims) interact with the text, ritually, cognitively or otherwise. The focus may be on individuals or on the community. It may concern the role of the Qur'an in everyday life, but it may also concern the role of the text in for example political rhetoric or legal discourse. ${ }^{2}$

The aim of the following text is to contribute to this latter, in a sense 'anthropological', study of the Qur'an as a 'living text'. This is done through examining the role of the text in Islamic Religious Education (IRE) in the city of Kisumu, Kenya. The article is based on data collected during several fieldwork sessions between the years 2004 and 2006. The framework is a larger project on Islamic education and social development financed by the The Department for Research Cooperation (SAREC) of The Swedish International Development Agency (SIDA). The data has been collected through participant observations, interviews with students and teachers, and lastly a questionnaire distributed among secondary school students at six schools, three that offer IRE, and three that do not. All the IRE teachers (in total 12), and around 20 secondary school students in Kisumu have been interviewed. In total, I participated at approximately 110 lessons of 
IRE, mainly, but not exclusively, at three of the secondary schools, but also at some Islamic club (see below) meetings. I also gained a lot of information in more informal conversations with teachers and students. I estimate the total number of Muslim secondary school students in Kisumu to be not above 300. Unfortunately, because of the turmoil surrounding some Danish cartoons of the Prophet Muhammad in spring 2006, the administration at one of the more secondary schools did not allow me to distribute the questionnaire there (they actually threw me out). This was unfortunate since that particular school was established rather recently, and has a relatively large number of Muslim students in form one and two. However, I consider the turn out of 137 answered questionnaires as rather satisfactory. Although I am of the view that the results should be treated with caution, I do not see any reasons why the students who chose to participate should not be seen as representative for Muslim high school students in Kisumu. I take this opportunity to thank the teachers and students who helped me in my work. The collection of the statistical data took place at the schools, and in my presence.

Although the article is empirical in focus, there are some theoretical aspects that need to be highlighted. In addressing the Qur'an in an IRE setting, I will distinguish between 'ritual' and 'cognitive' aspects of the text. By 'ritual aspect' I refer to the Qur'an as a text used in for example daily prayers and recitation, as well as notions of individual copies of the text as 'sacred', resulting in a system of rules and regulations concerning how individual copies are to be handled. The ritual aspect also involves notions of the Qur'anic text, and individual copies, as containers or vessels for divine power, baraka. The 'cognitive aspect' on the other hand, concerns the notions and use of the Qur'an as a source for information on religious creed, morals, knowledge and law. ${ }^{3}$

The theoretical framework used is taken from the field of the sociology of religion. I view religion in any society as part of that society's larger cultural complex. Religious views held by individuals, and religious rituals they perform, are a result of the society in which they live, and religious change is just an aspect of social change. The individual's religious views and behavioural patterns are upheld and made plausible for her or him through the interaction with others who share the same worldview. The individual is 
brought into the common worldview through the process of socialisation. This latter aspect is important in relation to the following. Education in primary and secondary schools, and the social interaction of students and teachers in this setting constitutes an important part of the students' secondary socialisation. Secondary socialisation is weaker than primary socialisation, which takes place in an earlier age and in the immediate surroundings of the home, but it is nevertheless important in shaping the meaning system of individuals later in life. ${ }^{4}$ IRE is part of the secondary socialisation into Islam as a system of meaning, for those students who partake in it.

\section{A very short overview of Islam and IRE in Kisumu}

The history of Islam in the western Kenyan province of Nyanza (in which Kisumu is the major urban centre) is still to be thoroughly mapped, but the Muslim presence dates back at least to the late 19th century. The history of Islam in the Nyanza province (in which Kisumu is the major urban centre) is still to be thoroughly mapped, but the Muslim presence dates back at least to the late 19th century. The percentage of Muslims in the total population in Kenya is a politically sensitive issue. According to the 2003 Kenyan Demographic and Health Survey Muslims constitute 6-8 per cent of the total population. The Wikipedia and the CIA World Fact Book state the figure of 10 percent. In his book Islam and politics in Kenya (2000), Arye Oded estimate the percentage of Muslims to be 20 percent, but Kenyan Muslims themselves usually suggest an even higher figure (sometimes as high as 40 percent!), and often express strong scepticism towards the official statistics.

In Kisumu, as in Kenya as a whole, the majority of Muslims are of African ethnicity, although there are Muslims of Arab and South Asian ethnicity as well. Most Muslims are Sunnis, belonging to the Shafi'i madhhab, but there are also communities of Twelver Shias, and Ismailiya Shias (Bohoras and Khojas). There is a small Ahmadiya (Qadiani fraction) community as well, with a centrally located mosque. Apart from these 'sectarian' divisions, there are also ideological divisions within the Sunni group, verbalised as a conflict on whether or not there is need for a religious 'purification' of 
local Islamic beliefs and practices. This latter division thus corresponds to what has been observed as a trend also in other parts of sub-Saharan Africa. ${ }^{5}$

IRE is a subject offered in some, but not all, primary and secondary public and private schools in Kenya. Its history dates back to the 1970s, when it was established as a Muslim counterpart to the already existing Christian Religious Education (CRE). ${ }^{6}$ In Kisumu, the subject is there at four secondary schools, and five primary schools. Other schools, although most have Muslim students, do not offer the subject. In these cases, Muslim students in primary school, and in the first two years of secondary school, have to take CRE instead. This is because religious education is compulsory. The subject may be dropped the last two years in high school. The survey conducted in 2006 showed that among the participating 137 Muslim secondary school students, three out of ten had studied IRE in primary school. The rest had studied CRE. This does not mean that the majority of the students did not receive basic religious education. Only $6 \%$ claimed that they had received no religious education at all. The rest had either gone to madrasa (see below), or had received private education at home.

IRE has the explicit double objective of providing basic knowledge of Islam as a religious tradition (e.g. its sources, rituals and history) and of moulding students into 'good' Muslims. Hence the secondary socialisation into the religious system of meaning is part of the very aim of the subject. IRE coexists with the traditional madrasa or chou education connected mainly to mosques, but differs from it in focus. The madrasa education (where Kiswahili or at times 'ethnic languages' such as for example Somali, are the main media) focuses on teaching basic skills in reciting the Qur'an in the Arabic language and basic knowledge of the hadith, sira and fiqh. ${ }^{7}$ IRE, on the other hand, has a wider scope. It covers topics such as Islamic history (worldwide and locally), different Islamic 'sects' (mainly Sunni and Shia) and morals. The teaching of IRE, like all subjects except Kiswahili, is supposed to be conducted in English, but in the classroom Kiswahili is often used, not least because the students are more comfortable communicating in that language. Unlike the madrasa education, there are furthermore official, national syllabuses for IRE for both primary and secondary schools. These were revised in 2002. 


\section{The Qur'an in the national syllabuses for IRE}

The syllabuses, issued by the Ministry for Education, offer a good starting point for investigating the role of the Qur'an in IRE. This is due to the influence these official documents have on the actual teaching. The syllabuses determine the areas to be covered. According to the syllabuses, IRE should be taught three lessons each week throughout secondary school and in classes 4-8 in primary school. In classes 1-3 in primary school, there should be two lessons each week. Each lesson in secondary school is 40 minutes, and in primary school 30 or 35 . The questions that will be posed in the final exams in standard eight in primary and form four in secondary school are related to the syllabuses. How the students perform in these final exams are of utmost importance for their future opportunities. In interviews with the IRE teachers, all stressed the importance of sticking to the syllabus in the actual teaching, and to cover the whole of it. Many students, and several of the teachers, identified IRE as a 'boost' subject. It is fairly easy to pass IRE, and high marks in IRE will 'boost' the total score in the final exams.

What then, do the syllabuses have to say about the Qur'an, and about what is to be taught in relation to it? In both the primary and the secondary school syllabuses, 'The Qur'an' constitutes a specific sub-topic. In primary school the focus is on the Arabic language and recitation. This is then similar to the training provided in the madrasa, and can be seen as revision for those students who have attended or attend that, and as an alternative for those who have or do not. In the general objectives for IRE it is clearly stated that the students should learn to read and write the Qur'an in "its original scripts [SIC]", 8 i.e. Arabic. In standard 1-4 the students are to be taught the basics of the Arabic language, in order to be able to read and write some selected suras. During the course of the eight years in primary school they are supposed to learn by heart al-Fatiha and the 22, shorter concluding suras of the Qur'an. It is explicitly mentioned that the students should be able to recite correctly and memorize these. The students are also supposed to be taught how to use these suras in their daily prayers, which then, together with the recitation and memorisation puts the focus on the ritual aspect of the Qur'an. In the syllabus there is however also the additional aim that the students should be able to "state the meaning of 
the given sura". ${ }^{9}$ Hence the students are not only expected to be able to use the Qur'an ritually, but also to understand its teachings, or rather what is perceived to be its teachings.

The cognitive aspect of the Qur'anic text comes more to the fore in the secondary school syllabus. Like in primary school, certain suras are singled out for further study. In form one, there are four such suras $(1,103,105$ and 110). These also appear in the primary school syllabus. ${ }^{10}$ In form two, the students should be able to recite only three verses of the second sura of the Qur'an, the throne verse 2:255 and verses 2:284-286 (all well known and loved in the Muslim world). ${ }^{11}$ In form three and form four the aspect of recitation is dropped, and instead understanding and explanation of meaning comes to the fore, for example in relation to the suras 24 and $49 .{ }^{12}$ That there is a stress on cognitive aspect of the Qur'an is furthermore evident in the way, unlike in the primary school syllabus, other topics (such as for example morals, creeds and Islamic law) are related to specific Qur'anic verses. Topics such as for example 'Forms of shirk', 'Significance of swalat [prayer]' and 'rights and duties of family members' are all accompanied, in the syllabus itself, by references to relevant verses. ${ }^{13}$ In the secondary school syllabus it is further clear that other aspects than ritual use and content of specific verses become important. The syllabus points out that the text itself has a history and that it was first revealed in a historical (or maybe rather 'mythological') context. Topics to be addressed in the course of these four years thus include: 'God's purpose for revealing the Qur'an', 'Modes in which it was revealed', its compilation, its teachings and its importance for Muslims. ${ }^{14}$

As mentioned above, the syllabuses have an important role in structuring the teaching of IRE in Kisumu. According to my interviews, different teachers have different ways of relating to it. Some will follow the syllabus down to the very letter, seeing their main task as being that of providing answers to questions that might appear in the final exams. Others prefer, according to themselves, a more holistic approach, viewing IRE as not only a school subject among others, but also as an opportunity to mould the students into good Muslims. 
While the syllabuses are important to take into account when addressing IRE in Kisumu, I hold textbooks to be less so. This is mainly due to the fact that those books, although they do exist, are not readily available for the students. The bookshops in Kisumu do not stock them, and only a few schools can afford to provide copies for each and every student. The students mostly rely on the notes that they take in class, or that the teacher provides them with. Textbooks will therefore be left out of this following, and instead I will now turn to the issue of how the Qur'an is discussed and handled in the classroom setting, although I will return to the syllabuses when relevant.

\section{The power, character and ritual use of the Qur'an}

As mentioned above, the ritual aspect of the Qur'an in terms of recitation and use in daily prayer is part of the teaching, especially in primary school. In interviews with primary school teachers they all concluded that this was actually not a very large part of the actual teaching, since most of the students had basic skills in these areas already when they entered standard one. This was because most of the students attended madrasa, or had a private teacher teaching them how to read Arabic and how to recite some basic verses. One teacher remarked that there might be students who did not have that kind of background, and that she in that case had to provide some extra sessions for them. Otherwise, she had tried to cover this part of the syllabus through making posters with transliterations of verses, hanging around the walls in the classroom. One primary school differed from the others in the respect. Learning how to read and recite the Qur'an in a correct way was here stressed more than in the other schools, and even more than what the syllabus actually demanded. This was due to the fact that the school was based on the notion of 'integration' of Islamic and secular teaching. Apart from IRE, the Muslim students of this school, called al-Mu'minun (i.e. 'the believers') Academy, were provided with additional teaching in Qur'an, hadith and fiqh, outside the school hours (45 minutes a day). Unfortunately, the teachers, who were very suspicious of my 'real' intentions, did not allow me to attend these extra classes. I, however, attended IRE lessons at the very same school, and could note that the students were indeed skilful in reading Arabic and reciting the Qur'an, compared to students at other schools. 
There are other examples in my observations of how the ritual aspect of the Qur'an came to the fore, although it was not a focal point in the teaching itself.

Take good care of the Qur'an. Look at how it is! [The female student points to the classroom copy of a paper back translation of the Qur'an]. The pages are falling out. Take good care of it. It is the word of God, and it is dirty! You will be held responsible if you do not look after the Qur'an.

This was a remark made by a chairlady at an Islamic club meeting I attended at one of the secondary schools. ${ }^{15}$ It relates to issues of ritual purity and impurity that were often brought up in class and in discussions among the students themselves. In the questionnaire that I distributed to the students I asked them to rate Islamic sins from 110, where 1 was the worst and 10 the least bad. I here included the following: Sex before marriage, drinking alcohol, eating non-halal food, touching the Qur'an while in a state of impurity, stealing, lying, taking bribes, fighting other Muslims, receiving interest from a bank and backbiting/slandering. While sex outside marriage was rated by $39 \%$ as the worst sin, touching the Qur'an while in a state of ritual impurity took a second position (32\% rated it as the worst $\sin$ ). The majority considered it a worse sin than stealing, drinking alcohol or fighting other Muslims. The discussion on by whom, and in which contexts, the Qur'anic text may be touched was vivid at times. In the secondary school context, the main question discussed was if girls in their menstruation were allowed to touch the mushaf, i.e. a physical Qur'an copy. Apparently this had been a recurring topic for a fairly long time. At a so called 'Awareness' event in 2004, organised by one of the secondary schools, inviting student from the other schools and external lecturers, the issue had, according to persons who participated, lead to a row. I did not attend the meeting myself, since I was not in the area, but from what informants told me, I could deduce two main positions in this debate. One position claimed that no one who is not ritually clean may touch the Qur'an. This included women in their periods, as well as non-Muslims. This view was supported with reference to the scripture itself. Verse 56:77-79 of the Qur'an states: “That this is indeed a Qur'an most honourable. In a book well-guarded, which none shall touch but those who are clean [mutahharun]" ${ }^{16}$.The other 
position was that other circumstances besides ritual purity had to be taken into account. I could observe the continuing debate throughout my fieldwork.

In February 2006 I attended an Islamic Club meeting at one of the secondary schools. This particular meeting was held at an all boys' school, but the discussion focused mainly on women and impurity:

Chairman: Ok, let's move on. There are many challenges for us Muslims in school. One of these concerns how to handle the Qur'an we are in the state of janaba. This mainly concerns girls having their periods.

The chairman posed an open question to his fellow students on whether girls in their periods are allowed to touch the Qur'an.

Chairman: Do we commit a sin when we allow them to touch the Qur'an in class.

Student 1: Yes

Student 2: Yes, if I happens during an ordinary class, but not if it happens during exams. They must be allowed to touch it during exams

Student 3: It is allowed to touch the translation, and if the Qur'an is used for study, it is also allowed.

Student 1: No, it is the same thing with the translation. It doesn't matter. She is not allowed to touch it.

Student 3: I've asked the imam at Jami'a mosque, and he says it is allowed.

The students discussed further the issue on when touching of the Qur'an is not allowed. They concluded that if a person is in a state of janaba, it is not allowed. Furthermore, they agreed that a non-Muslim is not allowed to touch it either. This latter view is particularly interesting. The IRE teachers at this school, who often read from the Qur'an in class and had their own copies, were non-Muslims (and female). The majority of students participating in the discussion did not accept the suggested differentiation in the quotation above between translations of the Qur'an and the Qur'an in Arabic script, a differentiation many Muslim scholars today make. Finally, the students did conclude that there are exceptions to the general rule that the Qur'an should not be touched while a person is in the state of janaba. One such exception is in education, another is if it is used for medical purposes, for example in the exorcism of spirits, i.e. jinns. The discussion also touched upon the interesting issue on how to handle the Qur'an in other format than as a book, for example on CD-ROMs or cassettes. No consensus was reached though, except for an agreement that the Qur'an in any form should not be brought into the toilet, 
neither may the Qur'an be recited there. I noted that the discussion engaged the students. This was also the case in the ordinary classes, not always to the liking of the teachers. One teacher saw the question on whether girls in their periods could touch the Qur'an or not as a token of a non-rational and superstitious attitude towards Islam among the students. Furthermore, he saw it as demeaning to women. He reproached one female student for referring to women as 'impure'. Another secondary school teacher commented on what he saw as an extreme form of reverence shown to the Qur'an and to the Arabic script. This was, according to him, a token of religious ignorance.

Teacher: Some believe that just because something is written in Arabic it is also something
that should be honoured. In earlier times, before, when we here found a piece of paper with
Arabic writing on it, we would pick it up, kiss it, take it home and put it between the covers
of the Qur'an. It could be anything. A manual for a radio or a medical recipe. Just because it
had Arabic letters on it we thought we had to honour it. Such a notion should not be there.
There are a lot of things that are not religious, but are written in Arabic. The Bible has also
been translated into Arabic. We have to work against this attitude.

Student 1: I've heard that if you drop the Qur'an on the ground. You should pick it up and kiss it seven times,

Student 2: I've heard three times.

Teacher: Why should you kiss it?

Student 1: To show respect. Some say love. You kiss the one you love.

Teacher: The one you love you kiss on the forehead. Where is the forehead of the Qur'an? This is the way it is. You should show the Qur'an respect, but it is not necessary to kiss it. I have not seen anywhere in the Qur'an or in the history of the Prophet where it says that you should kiss the Qur'an.

One can note that the teacher here took the opportunity to argue for a 'scripturalist' view on religion, i.e. Islam is what is to be found in the Qur'an and in the Sunna, against popular understandings of what the religion entails. This is an ongoing conflict in the local setting, as mentioned above, and it often appeared in the context of IRE, especially in this particular teacher's classes. Several of the teachers, however, complained of what they termed as a 'superstitious attitude' to Islam among the students and saw it as their responsibility to correct that attitude.

I did not observe the teachers discussing Qur'an as an object with power in itself, but questions relating to this popped up from time to time in the classroom. This notion is also widespread locally. Especially the notion of the Qur'an and Qur'anic text as a remedy for diverse forms of illnesses is commonplace. In the tiny bookstall outside the 
central mosque I could collect five titles on the healing power of the Qur'an. If you are suffering from illness, a local shaykh can make you some kombe, water in which a paper with Qur'anic verses written on it has been dipped until the ink is dissolved. In one classroom discussion on HIV/AIDS - a highly relevant topic in an area where HIV infections are among the highest in the world - the following dialogue took place:

Student: The cure for it [HIV/AIDS] is the Qur'an.

Teacher: No, it is not. That is what they tell you in the mosques. The fact is that AIDS has no cure. A cure is something that cures a disease. The Qur'an does not do that.

Student: I've heard that if you read one of the 99 names [of God] a thousand times, you can cure incurable diseases.

Teacher: Do you believe in that?

Student: If God wishes so...

In an earlier interview with this particular teacher he stated that such a view on the Qur'an as a "cure" for HIV/AIDS was “rubbish". Other views of Qur' an as a protection against evil, a widespread notion in Islamic tradition, also came up at times. One such example was in a discussion on 'wet dreams' at an Islamic Club. It was at the all male school mentioned above, and the topic was quite popular. Several of the boys apparently found the discussion amusing. After some lengthy elaboration on what exactly constitutes a "wet dream", one boy, who apparently did not find the discussion that amusing, rose and told the others that there was a perfectly useful 'cure' for this problem: The reciting of particular verses from the Qur'an before going to sleep. The Throne verse was mentioned in particular.

To conclude, the aspect of the Qur'an as an object to be used in rituals, through recitation and prayer, is there in the teaching. Although the students display views on it as a container for extraordinary divine power, this seldom forms part of the actual teaching in class. The notion that Islam is a modern and rational religion, widespread in contemporary Islam, makes such elements problematic. The well-known Islamic and Qur'anic studies scholar Andrew Rippin has identified the downplaying of 'superstitions' and miraculous elements in the Qur'anic text as a notable trend in modern Muslim Qur'an interpretation. ${ }^{17}$ This holds true also for notions of the powers of the text as discussed above. This is not to say that views of the extraordinary character of the Qur'an are lacking in the teaching. They are there, but are more connected to the content of the 
text than to possible effects when the text is recited or touched. In modern Muslims understandings of the Qur'an, the traditional notions of its miraculous character take other forms to which I will turn now.

\section{The superiority of the Qur'an}

IRE teachers are not very well paid. One way of getting extra income is to compile and sell sets of questions and answers that the students can use to revise for the final exams. In one such set of revision questions, locally produced in Kisumu, that I bought for 300 Kenyan shillings the teachers had included a couple of questions on the nature of the Qur'an. Here it is identified as the 'eternal miracle of Islam' and as the 'word of God' protected by him from 'any human interference and corruption', but there is no mention of baraka, in the sense of the Qur'an having curative powers or the like. The Qur'an's particular character, in relation to other books, is instead of another kind. The book is the last revelation to mankind, containing information about the 'hidden world', correcting earlier revelations that had been corrupted by mankind. It provides a superior code of conduct and is a source for knowledge of the will of God, or more specifically of Shari'a. Its effects are seen both on the individual and community level. It 'purifies one's morals', 'unify [SIC] the society' and 'strengthens the relationship between husband and wife'. It contains information on rituals and 'help Muslims solve their problems through the Quran [SIC] directly or indirectly'. It is further 'a source of knowledge' (not further specified). Reference is also made to its extraordinary poetic style and to the traditional notion of the Prophet Muhammad as an illiterate, and therefore not able to produce such a text himself. $^{18}$

Looking at these 'revision' questions it is clear that the miraculous character of the Qur'an is thus here located in its content, its history and its literary style. This attitude towards the Qur'an was also the dominating feature in the teaching, and here another interesting feature emerged. One teacher gave the following presentation of why the Qur'an is not the word of Muhammad, but the word of God.

Well, first of all the Qur'an challenges people to produce a 'sura like it' in verse 2:23. The opponents of the Prophet could not do that [...] and also, the Qur'an contains prediction of what is to be in the future. These miraculous verses prove that it could not have been written 
by a human being. There are also verses that contain scientific proof. I have given my book on science in the Qur'an to a student, and he hasn't returned it, otherwise I would have shown you. The poetic style of the Qur'an was also superior to all other poetry at that time.

Allah has also said that he would protect the Qur'an against changes, and he has done so.

During another lesson, the same teacher tried to sell CD-ROMs to the students containing, among other things, material produced by the popular Turkish apologist Harun Yahya. The teacher described Yahya as "a shaykh that has scientifically proven the truths of the Qur'an'. The notion of 'scientific proofs' of the Qur'an is very popular and widespread among Muslims in Kisumu, as it is among Muslims worldwide. The basic argument is that the Qur'an contains scientific information, in for example the fields of embryology, biology, medicine, astronomy and geology that has come to be known to mankind only in recent times. This is the theme in the popular book The Bible, the Qur'an and Science by the French physician Maurice Bucaille, which has triggered a whole trend of 'scientific exegesis' since it was first published in French in 1976. ${ }^{19}$ Today this genre of 'scientific tafsir' is still popular, which can be seen not least on the Internet. The author Maurice Bucaille may be less known among my informants, but the trend of 'bucaillism' is. In one Islamic Club meeting that I attended the students were discussing a possible exam question: "Compare the Qur'an to other books". They identified some points, for example that the Qur'an was revealed to all people and earlier books had been revealed only to some "nations". One of the students compared the Qur'an and the Old Testament in the following way:

\footnotetext{
The earlier scriptures have been corrupted by the Jews and the Christians. The Qur'an speaks of science. The Old Testament doesn't. It speaks of magic, for example in the section on Moses and the sorcerers of Pharaoh. The Qur'an, on the other hand, brings science. There is a shaykh who has written a book about how much science there is in the Qur'an. I can't remember his name now, but I have the book at home so I can check. He writes that ten per cent of the content of the Qur'an is about science. The Qur'an was revealed in the age of science.
}

\section{The Qur'an as a source for religious knowledge and morals}

Hence, the miraculous character of the Qur'an is mainly an issue connected to its content and style, and it is indeed its content that stands in focus in the teaching in class. Among the teachers I could detect certain scepticism towards madrasa education. They all stressed the need for Muslims not only to learn how to recite the Qur'an in Arabic correctly, but also to understand the text, and text's perceived teachings. In discussing in 
what way the Qur'an has been preserved one teacher made the following remark on translations:

One way in which the Qur'an has been preserved is through translations. I know that some of the 'ulama don't like the Qur'an to be translated to other languages. But how can it be understood by those who do not know that language if it is not translated. Learning the Qur'an will then only be a matter of learning to recite it without understanding anything. I have said this several times. I don't want you to be like babbling sheep, like parrots. I want you to understand what you are reading.

As mentioned above, IRE has a double goal of providing information about Islam and moulding students into good Muslims, and different teachers focus on different aspects of this. According to the syllabus, all teachers should cover the following areas: Qur'an, Hadith, Devotional acts, Moral teachings, Pillars of Iman (faith), Mu'amalat (transactions) and the History of Islam. In addition, the primary school syllabus mentions the areas of Festivals and ceremonies and al-Ilm (knowledge) as well, ${ }^{20}$ and in the secondary school syllabus there is the section on Muslim scholars. ${ }^{21}$ The Qur'an serves as a reference point in several of these areas. In primary school the teaching on the Qur'an involves, as mentioned above, mostly memorisation and recitation. In secondary school though, there are other areas in focus. These concern the history, or rather perceived history, of the text itself. According to the syllabus, topics to be covered include events in the revelation of the Qur'an, means through which this revelation was made, God's reasons for revealing it. The teacher is furthermore expected to cover how the Qur'anic text was compiled during and after the death of the Prophet. The same applies to its standardization, including also the diacriticalisation. Lastly, the students are expected to know, at the end of their studies, how the Qur'an has been preserved throughout the ages. Apart from the subject of the Qur'an itself, references to the Qur'an appear in other contexts as well. The history of Islam in primary school involves the 'salvation history' within the Qur'an, i.e. of the events from creation and onwards, including the narratives on earlier Prophets mentioned in the Qur'an. I could here observe how the text of the Qur'an was used as a starting point for narrations expanded by the teachers with material gathered elsewhere. In secondary school, all the teachers' presentations on creed, rituals and legal matters were backed up by clear references to and quotations from the Qur'an. The students were encouraged to carefully write down these references, and use them in their future final exams. 
Although high school teachers and students alike often recited verses in Arabic when addressing them for the first time, the elaboration on the content was on the English translation, most commonly, and not surprisingly, the translation by the Indian reformist Yusuf Ali. ${ }^{22}$ From a historical perspective, translations of the Qur'an into other languages than Arabic have at times been controversial, especially among the 'ulama. The notion that the Qur'an is exceptional in language and style, and 'inimitable', i.e. the doctrine of $i$ 'jaz, has made some scholars view translations with scepticism. ${ }^{23}$ The legitimacy or illegitimacy of translating of the Qur'an was not an issue in IRE in Kisumu. Although teachers and students (at least in secondary school) would agree that the Arabic text is superior to the translations, the difference between original and translation was not elaborated in class, and in practice there was no difference when the text was discussed. The discussion related above, on whether translations may be touched by unclean persons, points to the fact that the distinction was not that clear. That translations are rather unproblematic is displayed in the revision questions mentioned above. One of the 'questions' given and answered is how to "distinguish Tafsir from Quran translation". Here the evaluation of translations is positive: They provide "the interior meaning of the Qur'an", are "meant for all", and not only "for the learned". They do not "change the internal meaning of the Qur'an" and "has helped Islam". 24 There were instances in my classroom observations when translations actually appeared more important than the Arabic text. The introductory quotation points to a recurring event in one of the secondary schools. The teacher made an extra effort in advancing the use of the English translation. On one occasion he was teaching about the attributes of God to be found in the Throne verse:

Teacher: It is important that you learn this verse by heart. It is just like al-Fatiha. And I don't
mean that you should learn it by heart in Arabic, because you all already know that. I mean
that you should learn to recite it by heart in English. [...] It is important that you learn it by
heart because in the upcoming exams it should be there. If you don't know the translation by
heart, you will not know what to write when for example the question 'What are the
teachings of al-Fatiha' comes up. You know how to recite it in Arabic, but you do not
understand it when you recite it. A good way to learn how to recite al-Fatiha is to use it as a
$d u^{\prime} a$ in English. The homework for tomorrow is to learn to recite al-Fatiha in English.

He gave the task of memorising al-Fatiha to all the Muslim pupils during that week, and threatened (jokingly) those who did not memorise it with kiboko, i.e. the cane. Al-Fatiha 
is of course a central sura in the ritual life, and every student knows it in Arabic. But that would not help them in their exams.

The role of references to the Qur'an in secondary school teaching on creeds, ritual, legal matters and morals is, naturally, to give support to the statements made on how to believe and act as Muslims. In most cases such references to the Scripture were not discussed further, but just given. According to the teachers in secondary school, being able to refer directly to the Qur'an was especially important in relation to the exams, in order to receive the highest possible marks.

Some elaborations on Qur'anic verses had little direct relevance to the students' lives, as Muslims living in Kenya. One example is the topic of Islamic penal law, which is not practiced in Kenya, contrary to Islamic family law, which is practiced within a legal system of separate qadi-courts. ${ }^{25}$ Discussions on Islamic penal law, and in particular $h u d u d$, were thus, hypothetical. Nevertheless Islamic penal law was discussed in detail in class due to the strong foundation in the Qur'anic text, and the fact that the topic is mentioned in the secondary school syllabus. When hudud were discussed teachers and students alike stressed the 'wisdom' and 'benevolence' behind these punishments, especially noting the understanding of them as methods of religious 'purification' relieving the punished person from the otherwise eternal punishment in the hellfire. Furthermore, there were voices among teachers and students alike that did argue for the positive effects that the application of such punishments would have in Kenya, pointing out the high crime rate and the spread of the HIV virus. Some Muslims in Kenya may harbour dreams of instituting a separate Islamic system of penal law. One teacher clearly expressed his wish that Muslims should be allowed to practice hudud, as did many students. $^{26}$

Other issues pertaining to Islamic law, but also morals, are less hypothetical and did at times spark discussions. This was less so in primary school than in secondary school. I could observe how especially issues pertaining to gender and gender roles led to reactions. The oft-repeated 'truth' in the IRE classes, as well as outside of these classes, 
that 'women are not discriminated against in Islam', did at times come into conflict with the teachings, especially on Islamic law, and on the Qur'an. It was obvious that the teachers at times had some difficulty handling the conflict. When outlining the rulings on polygamy and verse 4:3 in the Qur'an, one teacher stressed what he viewed as the exceptional circumstances that have to be there in order for a man to be allowed to marry more than one woman. He identified these circumstances as the husband's 'hypersexuality', illness of the wife and a surplus of women due to war. Hence, he provided 'rational' explanations for the Qur'anic rulings. In this, he was acting in accordance with the syllabus, which states that both conditions and reasons for polygamy should be addressed. ${ }^{27}$ Another area that appeared to provoke especially the female students was the issue of mirath, i.e. the rules of succession. I could observe several times how female students objected to the notion that they should inherit half of what their brothers inherit. When I interviewed students, I asked what they liked least among the topics covered in IRE. All female students answered mirath. At one occasion when one of the teachers talked about inheritance, a female student raised her voice: "But that is not fair! Why should women inherit only half?" The teacher smiled at her, and said that he would convince her of the fairness in the distribution. He started to give reasons why there should be a difference in portions. His explanation was somewhat lengthy and complicated, but contained the well known argument that since men have the obligation to support the family, they need a larger share of the inheritance. After this elaboration, he asked the student "Have I convinced you of the wisdom contained in the Qur'an on inheritance?" The girl answered "No. I still think it is unfair, but I guess I have to accept it anyway".

In the area of gender relations I could note how references to the Qur'an was also used in the discussion between the students, especially between female and male students. On one occasion there was a discussion on the possibility of female leadership. One female student claimed that a woman could lead a country, if she just dressed moderately. One male student reacted strongly, referring to verse 4:34 in the Qur'an: "NO! According to the Qur'an, men are the qawwamun over women. A woman cannot lead men. It is wrong." Although he claimed that the word of God was clear on the issue, he also 
referred to biological differences between men and women in order to support his view. 'There are times when women are moody and loose all common sense. For example when they are pregnant. They cannot make the right decisions. They become totally crazy." Another male student opposed him, claiming that today, in contrast to the time in which the Qur'anic verse was revealed, women have gained access to education and are as qualified as men to act as political leaders. After some discussion among the students, the teacher intervened, asking the student who supported the idea of female leadership: "So the words of the Qur'an are old fashioned." To this, all the students responded in chorus: "NO!!!” A third, male, student here attempted a compromise: "I don't want to go against the Qur'an. A woman may be a leader, but they cannot have the highest positions in society. That is how I understand the verse. A woman can, for example, be the chairperson of the Islamic Club." At the end of the lesson, the teacher provided the 'Islamic view' on the issue:

\begin{abstract}
This is the way it is according to Islam. Women have a very special role in society. It is them who give birth to and raise the children. Among those she gives birth to and raises are the future political leaders. This is where she has her very important role. [...] You should not believe that the Qur'an can become outdated. All the verses are there, and they are all working well. They do not have to be changed in order to fit with the times.
\end{abstract}

This quotation sums up one basic element in the role of the Qur'an in the teaching of IRE. The authority of the text is unquestioned, but on the other hand it needs to be justified with references to its 'wisdom' in relation to biological and social 'facts".

\title{
Conclusions
}

What then can be said concerning the role of the Qur'an in Islamic Religious Education (IRE) in the city of Kisumu, Kenya, and what possible long time effects may this have on the students' perceptions of the Scripture. While the former question is fairly easily answered, the latter is less so. It would demand a thorough investigation involving lengthy interviews with the students. All I can do here is to speculate, on the basis of the above. My conclusions are thus to be understood rather as a set of hypothesises, than as a definitive answer.

IRE is intended to serve as a part of the secondary socialisation of the children and young adults into Islam as a worldview and a system of meaning. This is also one of the explicit 
goals of the subject, expressed in the syllabus. It also clearly appeared in my interviews with teachers. IRE is not only teaching about Islam, but also the moulding of Kenya's future Muslims. I claim that part of the teaching on the Qur'an in IRE could further a process, mainly on the individual level, that runs counter to these very intentions.

Firstly, concerning the ritual aspect: From the material presented above I conclude that among the IRE students there are views of the Qur'an as a sacred object in itself. This comes to the fore in comments on its curative powers and the discussion on 'he [or in this context rather often she] who is not pure' should not touch the Qur'an. Notions of purity and impurity connected to the handling of the physical copies of the Scripture, points to an attitude where book itself is, to speak with Durkheim, 'set apart and forbidden", ${ }^{28}$ at least in the discussion. I could note that the verbalised views here at times appeared to be in contradiction with the actual way copies were handled, both in the school setting and outside of it. However, such views on the text, and also of other ritual object, are commonplace in everyday life among Muslims in Kisumu, as it is elsewhere in the Muslim world. Madrasa education, which most of the students have had access to, further emphasise the ritual aspect of the Qur'an. Since many attend madrasa from a rather early age (even two or three year olds may attend) it constitutes part of the primary socialisation. The stress in madrasa is not on the content of the Qur'an, but on the Arabic script, and on correct recitation and memorisation, at least for the younger students. This further strengthens the ritual aspect of the Qur'an. The Qur'an should be recited and memorised for its own sake, and not mainly for its cognitive content.

In the context of IRE, the approach to the text is different. The syllabus and the teaching influenced by it, in several ways downplay the ritual aspect of the Qur'an, although maybe not intentionally. It is the cognitive aspect that is stressed. The Qur'an here primarily becomes a book of divine instructions, rather than a divine text. This holds true in particular in the secondary schools. It was noted above that teachers at times reacted to the 'superstitious attitude' towards the Qur'an and towards Islam among the students. What they termed superstition could also be interpreted as a display of the students' notions of the 'sacredness' of the text. The criticism of the teachers thus displayed 
elements of 'demystification", or to speak with Weber 'disenchantment”, of the Qur'an in the classroom setting. ${ }^{29}$ By 'demystification' I here mean that the Qur'an is deprived of some of its supernatural characteristics. One aspect of this, as will be discussed further below, is the integration of the Qur'an into an overarching rational system of meaning. Other aspects of IRE can be said to favour this attitude of demystification of both the Qur'an, and of Islam in general. IRE is a school subject among others in a formal national educational system. This has bearing on the way the subject is taught, what it contains and in the end maybe also on the way in which the students actually perceive Islam. Again, it is relevant to compare with the madrasa. The latter is less formalised, and more tied to specific religious institutions and functionaries, than to impersonal, secular educational machinery. There is for example no national syllabus for madrasa education. In the context of IRE as a subject, Islam is given a precise amount of time in which is should be pondered upon and discussed each week. What the teaching should cover is determined by anonymous official documents that identify the core of the religious tradition, neatly arranged in sub-topics. The process at work here is what Dale Eickelman and James Piscatori has termed as the 'objectification' of Islam. ${ }^{30}$ It clearly becomes a delimited 'object' to be reflected upon. This would seem to work against the notion, often expressed in the context of IRE that "Islam is not a religion, but a way of life". On the contrary, IRE clearly makes Islam into a 'religion", i.e. as a thought system, a system of rituals, morals and law, a system that can be studied and discussed 'from the outside' at a specific time, in a specific place and detached from everyday life. Furthermore, IRE is an examinable subject, and the perceived role of it as something that can be used to 'boost' the results in the final exams, further strengthen the objectification. In my interviews and conversations with teachers and students it was clear that the 'moulding' goal of IRE was subsumed under the all overarching goal of 'passing the exams with good grades". What has been said here applies to the subject of IRE as a totality, but also to the teaching on Qur'an, especially in secondary school. For example, references to verses are here to the memorised, not primarily because they contain any inherent truth or wisdom (or for that matter power), or because they will guide the students in their everyday life, but because citing them in the final exams will be rewarded with higher marks. Knowing the Qur'an 
by heart is not a goal in itself, but a means to achieving other, 'profane' goals. This goaloriented, rational attitude towards the Qur'an furthers demystification.

Another aspect of the demystification of the Qur'an come into the teaching through the stress on the need for understanding its content, and the view, expressed by some teachers, that this is more important that being able to recite verses by heart. In this, the Qur'an in a way becomes a source for information, just like other books used for that purpose in school. The rather relaxed attitude towards translations of the Arabic original text, and the focus on translations in the actual teaching, further this image of a text like any other. In this process, the authority of the text may be questioned, which, as can be seen above, actually happened in class, although in a modest fashion. There are several examples in my material indicating that the authority of the scripture is not taken for granted. This is shown by the way teachers elaborated on controversial themes in the scripture (mainly gender issues), and tried to rationally justify them. Contrary to what some teachers claim, this do mean that the Qur'an, or rather perceptions of its meaning, is in a way changed to fit the times, or rather to fit the value system that the students and the teachers actually embrace. Elements in the text cannot be accepted as they stand, just because God says that they are just and good, they have to be defended in relation to what is generally believed to be just and good, in Kisumu in the beginning of the $21^{\text {st }}$ century. References to for example biology, particular social circumstances and purification from sins in the case of Islamic law, are references whose purpose is to justify the content Qur'anic text in a time when it is questioned by what in reality then becomes a higher authority, i.e. a meaning system greatly affected by the ideals of modernity such as equality, rationality and an understanding of the universe based on the natural sciences.

One should, however, note that there are elements in the teaching where there are attempts to further notions of the Qur'an's as being in one way or the other exceptional. These attempts are, however, influenced by the fact that they are put forward in a world that is, at least in some areas and to many people, demystified. The attempts are clearly related to the sources of authority that operate in such a demystified world. This is most striking in the example of "scientific tafsir". Such interpretations serve an important role 
in contemporary Islam, especially among Muslims who are in one way or the other acquainted with modern natural sciences, which would include secondary school students in Kenya. However, what this way of interpreting the Qur'an, and its popularity, actually indicates is that the Qur'an's exceptional character is something that some Muslims do not accept at face value. It is something that has to be proven by what then in reality, and unwittingly, constitutes a higher authority than the word of God, i.e. secular, modern natural science. The attempt at 'remystification' that the 'scientific tafsir' represents, actually accepts the demystification that has been a result of the expansion of natural science as a mode of explaining the world.

The teachings and discussions on 'hypothetical' issues, e.g. the hudud, could have contributed to an image of the Qur'an as containing a 'truth' that holds regardless of the social circumstances, adding to its 'sacred' character. Even in this context, however, rationalisations give the impression that the Qur'an contains a message that is justifiable mainly in relation to existing value systems and social facts, hence subsuming the text to the test of the times.

Whether or not the rationalisations and demystifications of the Qur'an that appears in class have any effect on perceptions of the Qur'an among the students when outside of the classroom, I am not in a position to say, but is surely is an alternative to the views of the Qur'an that do exist in the local setting. IRE is an arena where the religion becomes an object for discussion and reflection, and an arena where the otherwise unthinkable questions relating to the 'truth' of its content actually may be posed. Just posing the question means that the 'truth' of the Qur'an is no longer taken for granted. Morals and worldviews work best when they are not reflected upon, when they are seen as part of the 'natural' world, part of the everyday knowledge that is taken for granted. Therefore, it is at least possible that the discussion on the Qur'an in class, and in the school setting as a whole, has an effect at least on the students' way of relating to the cognitive aspect of the Qur'an. The morals, dogmas and legal aspects of the Qur'anic message is something that can be brought into question in relation to what takes place in their surroundings and the alternative value systems and systems of meaning that exists both locally and globally. 
This holds true in particular in relation to issues that engage young people in Kisumu, e.g. education, popular culture, relations between the sexes, love and sports. The ritual aspect of the Qur'an might be less affected. Since notions of the 'power' of the Qur'an and its 'sacred' character are not an issue specifically pondered upon in class, this aspect may be less challenged in the context of IRE, and may continue to play an important role in the everyday life of the youngsters.

I thus conclude that the way the Qur'an is approached in the context of IRE, reduces the aspect of the Qur'an as a sacred object, and instead stresses it as a cognitive source for knowledge, guidance and norms. This latter aspect, however, may become less 'real' or 'sacred' to the students due to the way it is rationalised and subsumed to the 'test of time". It becomes a text that is examinable, understandable and at times also questionable. More importantly though, the Qur'an is integrated into a goal oriented educational system, and distanced from everyday life through being allocated a specific time and place. The notion of the Qur'an as a mysterious object surrounded by taboos and containing miraculous power may not be affected at all in this process. It is still very much a part of everyday life outside school, an important part of the primary socialisation into the religious tradition, and hence part of a shared system of meaning that is not generally questioned.

\section{References}

Ali, A. Yusuf, 1983: The Holy Qur'an. Text, translation and commentary, Amana Brentwood.

Berger, Peter, 1967: The sacred canopy. Elements of a sociological theory of religion, Doubleday, New York.

Central Bureau of Statistics (CBS) (Kenya), Ministry of Health (MOH) (Kenya), and ORC Macro. 2004. Kenya Demographic and Health Survey 2003. Calverton: $\mathrm{CBS}, \mathrm{MOH}$, and ORC Macro. (available from www.cbs.go.ke)

Cornell, Vincent J., 1995: “Qur'an: The Qur'an as Scripture”, in: J. Esposito (ed.) The Oxford Encyclopaedia of the Modern Islamic world, Oxford University Press, New York. 
Eickelman Dale.F. \& James Piscatori, 1996: Muslim Politics, Princeton University Press, Princeton.

Evers Rosander, Eva, 1997: "Introduction: The Islamization of "Tradition" and "Modernity"”, in: Eva Evers Rosander \& David Westerlund (eds.) African Islam and Islam in Africa. Encounters between Sufis and Islamists, Hurst \& Co, London.

Graham, William A., 1985: “Qur'an as spoken word”, in: Richard C. Martin (ed.) Approaches to Islam in religious studies, University of Arizona Press, Tucson.

Kahumbi, N. Maina, 1995: "The Role of the Madrasa System in Muslim Education in Kenya", in: S. S. Yahya \& M. Bakari (eds.) Islam in Kenya. Proceedings of the National Seminar on Contemporary Islam in Kenya, MEWA Publications, Nairobi.

Kisumu Tuition Services (n.d.) K.C.S.E. Islamic religious education revision.

Lacunza-Balda, Justo, 1997: "Translations of the Quran into Swahili, and contemporary Islamic Revival in East Africa", in: Eva Evers Rosander \& David Westerlund (eds.) African Islam and Islam in Africa. Encounters between Sufis and Islamists, Hurst \& Co, London.

Lessa, William A. \& Vogt, Evon Z. (eds.), 1979: Reader in Comparative Religion. An Anthropological Approach, Harper \& Row, New York.

Lester, Toby, 1999: "What is the Quran", in: The Atlantic monthly, January.

McGuire, Meredith, 2002: Religion. The social context, Wadsworth, Belmont.

Ministry of Education, Science and Technology, 2002a: Primary education syllabus, Volume 2, Kenya Institute of Education, Nairobi.

Ministry of Education, Science and Technology, 2002b: Secondary education syllabus, Volume 2, Kenya Institute of Education, Nairobi.

Oded, Arye, 2000: Islam and Politics in Kenya, Lynne Rienner Publishers, London.

Rippin, Andrew, 2005: Muslims. Their Religious Beliefs and Practices, Routledge, London.

Robinson, Neal, 1997: "Secterian and Ideological Bias in Muslim Translations of the Qur'an”, in: Islam and Christian-Muslim relations, No. 3.

Said. Ahmed. S., 1995: “An outline of Islam in the Nyanza Province”, in: Saad S. Yahya 
\& Mohamed Bakari (eds.) Islam in Kenya. Proceedings of the National Seminar on Contemporary Islam in Kenya, MEWA Publications, Nairobi.

Said, Ahmed. S., 2004: "The background of Islamic Religious Education in Kenya" (unpublished article).

Stenberg, Leif, 1996: The Islamization of Science. Four Muslim Positions Developing an Islamic Modernity, Almqvist \& Wiksell International, Stockholm.

Yahya, Saad. S., 1995: “The Uses and Abuses of Waqf”, in: Saad S. Yahya \& Mohamed Bakari (eds.) Islam in Kenya. Proceedings of the National Seminar on Contemporary Islam in Kenya, MEWA Publications, Nairobi.

Jonas Svensson is $\mathrm{PhD}$ and lecturer at the section for humanities, Halmstad University, Sweden

\footnotetext{
${ }^{1}$ For some of the controversial issues surrounding this, see Lester 1999.

${ }^{2}$ For a discussion on the different ways to approach the text, and a call for a more anthropological approach see Graham 1985.

${ }^{3}$ Although he does not use the terms 'ritual' and 'cognitive", religious studies scholar William A. Graham points to a differentiation in his contribution to the anthology Approaches to Islam in religious studies (1988). According to him, Islamic studies scholars and religious studies scholars have, in the study of the Qur'an, to a large neglected the ritual aspect. Graham 1985.

${ }^{4}$ This is a very brief summary of the main points in my perspective, which is totally in line with what sociologist of religion Meridith McMguire outlines in the first two chapters of her book Religion. The social context (2002), which in turn is a development of the "sociology of knowledge"-perspective on religion represented mainly by Peter Berger.

${ }^{5}$ See e.g. the discussion on 'African Islam and Islam in Africa' in Evers Rosander 1997.

${ }^{6}$ Oded 2000:97; Salim 2004.

${ }^{7}$ For an overview, see Maina 1995.

${ }^{8}$ Ministry of education, science and technology 2002a:5.

${ }^{9}$ Ministry of education, science and technology 2002a:183-206.

${ }^{10}$ Ministry of education, science and technology 2002b:80.

${ }^{11}$ Ministry of education, science and technology 2002b:84.

${ }^{12}$ Ministry of education, science and technology 2002b:87, 91.

${ }^{13}$ Ministry of education, science and technology 2002b:80, 81, 82 passim.

${ }^{14}$ Ministry of education, science and technology 2002b:84, 87 passim.

${ }^{15}$ Islamic Clubs exist in all the secondary schools in Kisumu, also those that do not offer IRE, and in some of the primary schools as well. They are part of the schools' extra curricular activities.

${ }^{16}$ The quotation is from Yusuf Ali's translation of the Qur'an.

${ }^{17}$ Rippin 2005:230

${ }^{18}$ Kisumu Tuition Services (n.d.):4-7

${ }^{19}$ For a thorough presentation and critical analysis of Maurice Bucaille and his ideas, see Stenberg 1996. The term 'scientific exegesis' is borrowed from Robinson 1997:271, who traces its beginnings further back than 1976 and the publishing of Bucaille's book.

${ }^{20}$ See e.g. Ministry of education, science and technology 2002b:184.

${ }^{21}$ See e.g. Ministry of education, science and technology 2002b: 90.
} 


\footnotetext{
${ }^{22}$ This translation is the most widespread, not least since it has been backed by the Saudi Arabian $d a$ ' $w a-$ machinery (Cornell 1995:392)

${ }^{23}$ See Cornell 1995:390-391. For the discussion in a local East African context, concerning translations into Kiswahili, see Lacuza-Balda 1997.

${ }^{24}$ Kisumu Tuition Services (n.d.):5

${ }^{25}$ In the attempts to write a new constitution, the issue of the qadi-courts has been one of the more hotly debated. Muslims participating in the public debate have reacted strongly to suggestions that these courts should be abolished, seeing it as an attack on the Muslim community in the country.

${ }^{26}$ According to the survey, more than half of the students strongly agreed, or agreed to some extent with the statement 'Muslims should be allowed to practice Islamic punishments (hudud) in Kenya (e.g. flogging and stoning)".

${ }^{27}$ Ministry of education, science and technology $2002 \mathrm{~b}: 82$.

${ }^{28}$ Durkheim 1915, in Lessa \& Vogt (eds.) 1979:29.

${ }^{29}$ Peter Berger discussed a similar 'disenchantment' process in his The Sacred Canopy. He used the term 'disenchantment' in comparing Protestantism and Catholicism where he wrote that: 'At the risk of some simplification, it can be said Protestantism divested itself as much as possible from the three most ancient and most powerful concomitants of the sacred - mystery, miracle and magic.' (Berger 1967:111) This is the kind of divestment that I find also in the context of IRE.

${ }^{30}$ See Eickelman \& Piscatori 1996:37-45.
} 